\title{
TINDAK TUTUR GURU DALAM PEMBELAJARAN BAHASA INDONESIA DI KELAS VII TUNAGRAHITA SMPLB DHARMA WANITA PERSATUAN PROVINSI BENGKULU
}

\author{
Hardiyanti Fitria Rukmana ${ }^{1}$, Suryadi ${ }^{2}$, dan Irma Diani ${ }^{3}$ \\ ${ }^{1,2,3}$ Program Studi Pendidikan Bahasa dan Sastra Indonesia \\ Jurusan Pendidikan Bahasa dan Seni \\ FKIP Universitas Bengkulu \\ Hardiyantifitri6@gmail.com
}

\begin{abstract}
Abstrak
Tujuan penelitian ini untuk mendeskripsikan wujud tindak tutur ilokusi yang digunakan oleh Guru dalam pembelajaran bahasa Indonesia di kelas VII Tunagrahita SMPLB Dharma Wanita Persatuan Provinsi Bengkulu. Metode yang digunakan dalam penelitian ini adalah metode deskriptif kualitatif. Sumber data dalam penelitian ini adalah guru yang mengajar Bahasa Indonesia di kelas VII Tunagrahita. Data dalam penelitian ini adalah tindak tutur yang digunakan oleh guru. Teknik pengumpulan data dalam penelitian ini dengan metode simak, catat dan rekam. Teknik analisis data dalam penelitian ini dilakukan dengan langkah-langkah yaitu: (1) Menyimak dan merekan proses pembelajaran, (2) mentranskripsikan rekaman, (3) memberi kode pada data, (4) mengklasifikasikan data, (5) menganalisis data dan (6) menyimpulkan. Uji keabsahan data menggunakan uji kredibilitas yakni dengan peningkatan ketekunan dan diskusi dengan teman sejawat. Hasil penelitian ini ditemukan beberapa jenis tindak tutur yakni asertif meliputi tindak menyatakan dengan variasi menyatakan informasi (45 tuturan), menyatakan pemberitahuan (20 tuturan), menyatakan contoh (4 tuturan) dan menyatakan pembenaran (29 tuturan) Kemudian ditemukan pula tindak mengakui (3 tuturan), tindak menunjuk (37 tuturan), tindak mempertahankan (12 tuturan), tindak menyebutkan ( 3 tuturan), tindak membantah ( 7 tuturan) dan tindak mengucapkan salam ( 7 tuturan). Selanjutnya direktif meliputi tindak bertanya (184 tuturan), perintah (83) tuturan, mengizinkan (38 tuturan), melarang (5 tuturan), menasehati ( 6 tuturan), dan permintaan ( 7 tuturan). Kemudian ditemukan ekspresif meliputi tindak memuji (1 tuturan), mengkritik (31 tuturan), mengeluh (1 tuturan), menyindir (7 tuturan), menyalahkan (15 tuturan), berterimakasih (1 tuturan) dan deklaratif meliputi tindak memutuskan (5 tuturan).Tindak tutur yang digunakan oleh guru tersebut memiliki perbedaan dengan tindak tutur yang digunakan oleh guru di sekolah-sekolah umum yakni terdapat banyak pengulangan tindak. Dalam pengulangan tindak tersebut terdapat penggunaan dua bahasa yakni bahasa Indonesia dan bahasa Bengkulu, pengunaan padanan kata dan penggunaan teknik pancingan. Hal tersebut dilakukan oleh guru agar siswa yang memiliki hambatan intelektual mampu memahami dengan baik setiap maksud dari tindak tutur yang disampaikan oleh guru.
\end{abstract}

\section{Kata Kunci : Tindak tutur,Guru, Anak Tunagrahita}

\begin{abstract}
The purpose of this research to describe the form of speech acts llocution used by teachers in learning Indonesian in class VII Mentally Disabled SMPLB Dharma Wanita Persatuan Bengkulu Province. The method used in this research is descriptive qualitative method. Sources of data in this study are teachers who teach Indonesian in grade VII Mentally
\end{abstract}


Disabled. The data in this research is speech acts used by teachers. Data collection techniques in this research with methods refer, record and record. The data analysis technique in this research is done by the steps: (1) Listening and recording the learning process, (2) transcribing the recording, (3) coding the data, (4) classifying the data, (5) analyzing the data and (6) Concluded. Test the validity of the data using a credibility test that is by increasing perseverance and discussion with peers. The results of this research found several types of speech acts are assertiveness include acts declaring with variations of information (45 speech), states notices (20 speeches), states examples (4 speeches) and states justification (29 speeches) Then also found acts recognize ( 3 utterances ), Acts of appointment (37 speeches), act of defending (12 speeches), acts mention (3 speeches), acts of argument ( 7 speech) and acts of greeting $(7$ speech). Further directive includes questioning (184 speeches), command (83) speech, permits (38 speeches), prohibits (5 speeches), advises (6 speeches), and requests (7 speeches). Then found expressive include the act of praising ( 1 speech), criticizing (31 speech), complaining (1 speech), insinuating (7 speech), blaming (15 speech), thanking (1 speech) and declarative covering decision (5 speech). The speech acts used by the teacher differ from the speech acts used by teachers in the public schools, there are many repetitions of the act. In the repetition of such acts there is the use of two languages namely the Indonesian language and Bengkulu language, the use of match words and the use of fishing techniques. This is done by teachers so that students who have intellectual barriers are able to understand well every intention of the speech acts delivered by the teacher.

\section{Keywords: Speech, Teacher, Mentally Disabled Childhood}

\section{PENDAHULUAN}

Sebagai makhluk sosial, manusia
selalu berkomunikasi. Komunikasi
dilakukan untuk menyampaikan ide,
pikiran, perasaan dan gagasan melalui
bahasa. Bahasa menurut Chaer dan Agustina (2010: 11) merupakan sebuah sistem lambang, berupa bunyi, bersifat arbitrer, produktif, dinamis, beragam, dan manusiawi. Bahasa merupakan faktor penunjang tercapainya tujuan dari komunikasi. Dalam komunikasi terjadi peristiwa tutur dan tindak tutur. Peristiwa tutur merupakan proses terjadinya interaksi linguistik dalam satu bentuk ujaran, antara dua pihak yang meliputi penutur dan lawan tutur pada waktu, tempat dan situasi tertentu. Sedangkan tindak tutur merupakan gejala individual, bersifat psikologis, dan keberlangsungannya ditentukan oleh kemampuan bahasa si penutur dalam menghadapi situasi tertentu (Chaer dan Agustina, 2010: 50).

Komunikasi terjadi dalam berbagai aktivitas yang dilakukan oleh manusia. Salah satu aktivitas rutin yang dilakukan oleh manusia adalah proses pendidikan. Proses pendidikan merupakan kegiatan mobilisasi segenap komponen pendidikan oleh pendidik, terarah pada pencapaian tujuan pendidikan, sedangkan pendidik adalah orang yang bertanggung jawab terhadap pelaksanaan pendidikan dengan sasaran peserta didik (Tirtarahardja, 2010: 54). Berdasarkan pengertian tersebut dapat diketahui bahwa pendidik memiliki peran yang penting dalam proses pendidikan yakni sebagai fasilitator untuk membawa peserta didik mencapai kesuksesan dalam belajar. Pendidik atau sering disebut guru dituntut untuk mempu berkomunikasi dengan baik, sehingga pesan yang disampaikan dalam komunikasi 
tersebut mampu dipahami oleh siswa. Dengan demikian pemahaman siswa dalam kegiatan pembelajaran erat kaitannya dengan pemilihan tindak tutur yang digunakan oleh guru.

Tindak tutur yang digunakan oleh guru di sekolah-sekolah umum berbeda dengan tindak tutur yang dilakukan oleh guru di sekolah luar biasa, yang didalamnya terdapat anak berkebutuhan khusus. Anak berkebutuhan khusus awalnya dikatakan dengan anak yang memiliki kelainan. Flower mengemukakan bahwa anak yang memiliki kelainan merupakan anak yang memiliki kekurangan terhadap keadaan mental dan fisik (Delphie, 2009: 114). Sementara itu Ilahi (2013: 138) Mendefinisikan bahwa anak berkebutuhan khusus adalah mereka yang memiliki kebutuhan khusus sementara atau permanen sehingga membutuhkan pelayanan pendidikan yang intens.

Salah satu sekolah luar biasa yang memberikan pelayanan pendidikan untuk Anak Berkebutuhan Khusus adalah SMPLB Persatuan Dharma Wanita Provinsi Bengkulu. Sekolah tersebut membagi kelompok Anak Berkebutuhan Khusus atas empat kelas. Kelas A berisi anak yang Tunanetra, yakni anak yang memiliki hambatan dalam pengelihatan, Kelas B berisi anak Tunarungu dan Tunawicara, yakni anak yang memiliki hambatan dalam mendengar dan anak yang memiliki hambatan dalam berbicara, kelas $C$ berisi anak Tunagrahita, yakni anak yang memiliki intelegensi yang dibawah ratarata, kelas $D$ berisi anak Tunadaksa, yakni anak yang memiliki kelainan fungsi anggota tubuh akibat luka, penyakit, ataupun pertumbuhan yang tidak sempurna. Dari klasifikasi anak berkebutuhan khusus tersebut, anak Tunagrahita merupakan anak yang memiliki masalah dalam belajar yang disebabkan adanya hambatan perkembangan intelegensi, mental, emosi, dan fisik. Secara umum anak tunagrahita memiliki kemampuan intelektual di bawah rata-rata (Delphie, 2009: 127). Berdasakan hal tersebut dapat diketahui bahwa penggunaan bahasa dan pemilihan kosakata guru dalam proses pembelajaran sangat mempengaruhi keberhasilan belajar yang dicapai oleh penyandang tunagrahita. Dengan demikian guru memerlukan pengetahuan dan pemahaman yang lebih terhadap bahasa yang digunakannya maka dari itu penulis tertarik untuk melakukan penelitian tentang Tindak Tutur Guru Dalam Proses Pembelajaran Bahasa Indonesia di Kelas VII Tunagrahita SMPLB Dharma Wanita Persatuan Provinsi Bengkulu, hal ini dimaksudkan untuk mengetahui wujud tindak tutur yang digunakan oleh guru dalam proses pembelajaran Bahasa Indonesia di kelas VII Tunaghrahita SMPLB Dharma Wanita Persatuan.

\section{METODE}

Penelitian ini menggunakan metode deskriptif. Metode deskriptif berusaha untuk memotret peristiwa dan kejadian yang menjadi pusat perhatian, untuk kemudian digambarkan atau dilukiskan apa adanya sesuai dengan kenyataan yang ada (Susetyo, 2015: 11). Dalam penelitian yang ini tindak tutur yang digunakan oleh guru di digambarkan dengan sebenar-benarnya sesuai keadaan yang terdapat di kelas Tunagrahita. Sehingga penelitian ini bertujuan untuk membuat pencandraan atau deskripsi secara sistematis, dan akurat mengenai situasi atau kejadian, dan fenomena mengenai tindak tutur yang digunakan oleh guru dalam pembelajaran Bahasa Indonesia di kelas VII Tunagrahita SMPLB Dharma wanita persatuan provinsi Bengkulu.

Penelitian ini dilaksanakan kurang lebih satu bulan, yakni pada bulan Januari hingga bulan Februari 2017. Penelitian 
tersebut dilaksanakan hanya pada jam pelajaran Bahasa Indonesia, yakni setiap hari Sabtu, pada jam ke satu, jam ke dua, dan jam ke tiga. Penelitian ini dilaksanakan di SMPLB Dharma Wanita Persatuan Provinsi Bengkulu.

Sumber data penelitian ini adalah guru yang mengajar Bahasa Indonesia di Kelas VII Tunagrahita SMPLB Dharma Wanita Persatuan Provinsi Bengkulu. Proses pembelajaran tersebut termasuk ke dalam wacana lisan. Selanjutnya dari proses pembelajaran tersebut akan ditemukan tuturan yang digunakan oleh guru bahasa Indonesia tersebut selama proses pembelajaran berlangsung. Kemudian data dalam penelitian ini tindak tutur Ilokusi yang digunakan oleh guru tersebut.

Teknik pengumpulan data menggunakan metode simak. Metode ini merupakan metode yang digunakan dalam penyediaan data dengan cara peneliti melakukan penyimakan penggunaan bahasa. Metode ini memiliki teknik dasar, yaitu teknik sadap. Dikatakan demikian karena dalam praktik penelitian sesungguhnya penyimakan itu dilakukan dengan menyadap pemakaian bahasa dari informan. Selanjutnya teknik lanjutan yang digunakan dalam penelitian ini adalah teknik simak bebas libat cakap (SBLC). Dalam teknik ini peneliti menyadap perilaku berbahasa di dalam suatu peristiwa tutur dengan tanpa keterlibatannya dalam peristiwa tutur tersebut. Jadi peneliti hanya sebagai pengamat (Mahsun, 2007: 243). Kemudian dalam praktik penelitian ini diikuti dengan teknik lanjutan yang berupa teknik catat dan teknik rekam. Teknik catat yang dilakukan dalam penelitian ini hanya berupa cacatan kecil yang dilakukan oleh peneliti dalam proses penelitian, cacatan tersebut berkaitan dengan situasi penelitian. Selanjutnya teknik rekam yang dilakukan dalam penelitian ini terfokus pada perekaman suara yang berisi tuturan antara penutur dan mitra tutur. Proses perekaman dilakukan dengan menggunakan aplikasi perekam suara dari handphone merk Asus Zenphone 4 dan handphone Samsung. Langkah-langkah pengumpulan data dalam penelitian ini meliputi: (1) Manyimak dan merekam proses pembelajaran Bahasa Indonesia pada kelas VII unagrahita SMPLB Persatuan Dharma Wanita Provinsi Bengkulu, (2) mentraskripsikan rekaman, (3) mendata tuturan yang mengandung tindak tutur ilokusi, (4) memberi tanda pada data dan sumber data, (5) mengklasifikasikan data yang sudah diberi tanda sesuai dengan kriteria yang sudah ditentukan.

Analisis dalam penelitian ini menggunakan metode heuristik. Adapun metode heuristik yaitu jenis tugas pemecahan masalah yang dihadapi penutur dalam menginterprestasikan sebuah tuturan atau ujaran (Leech, 1993:61). Metode ini berusaha untuk mengidentifikasi tuturan yang mengandung jenis tuturan pada percakapan dalam proses pembelajaran antara guru dan siswa dengan merumuskan hipotesis-hipotesis dan kemudian mengujinya berdasarkan datadata yang tersedia. Apabila dalam proses analisis tidak teruji, dibuat hipotesis baru. Selanjutnya menggunakan analisis konteks SPEAKING yang dikemukakan oleh Dell Hymes (dalam, Chaer dan Agustina, 2010 : 48-49). Langkah-langkah yang dilakukan dalam menganalisis data penelitian ini adalah: (1) Mendeskripsikan maksud tindak tutur llokusi yang digunakan guru, (2) mengidentifikasi jenis tindak tutur, (3) mendeskripsikan jenis tindak tutur, (4) menarik kesimpulan.

Validasi data yang digunakan dalam penelitian ini adalah dengan uji kredibilitas menggunakan peningkatan ketekunan dan diskusi dengan teman sejawat sebagai upaya untuk menguji keabsahan data. 
Peningkatan ketekunan berarti melakukan pengamatan secara lebih cermat dan berkesinambungan (Sugiyono, 2008:370). Untuk meningkatkan ketekunan dalam penelitian ini dengan cara membaca berbagai referensi buku maupun hasil penelitian dan dokumen yang terkait dengan temuan yang diteliti.

\section{HASIL DAN PEMBAHASAN}

\section{Tindak Tutur Ilokusi Asertif}

Tindak tutur asertif yang ditemukan dalam penelitian ini meliputi tindak menyatakan yang memiliki variasi tindak menyatakan informasi: 45 tuturan, tindak menyatakan pemberitahuan: 20 tuturan, menyatakan contoh: 5 tuturan, dan menyatakan pembenaran: 29 tuturan. Selanjutnya ditemukan pula tindak mengakui: 3 tuturan, tindak menunjuk: 37 tuturan, tindak mempertahankan: 12 tuturan, tindak menyebutkan: 3 tuturan, tindak membantah: 7 tuturan, dan tindak mengucapkan salam: 3 tuturan.

Yule (2006:93) menyatakan bahwa asertif ialah jenis tindak tutur yang menyatakan apa yang akan diyakini penutur kasus atau bukan. Tuturan asertif yang digunakan oleh guru dalam proses pembelajaran Bahasa Indonesia di kelas VII Tunagrahita tersebut banyak mengandung tuturan yang merupakan informasi yang disampaikan oleh penutur yang merupakan guru kepada mitra tutur yakni siswa. Tuturan yang berisi informasi tersebut disampaikan oleh guru secara berulang-ulang dengan menggunakan penekanan yang sama pada setiap pengulangannya. Hal tersebut bertujuan untuk memberikan pemahaman mengenai informasi tersebut kepada siswa.

Berikut merupakan contoh mengenai tindak tutur pengulangan, atau tindak asertif yang berisi tuturan yang sama.

Guru : Lah ngerti? Paham Lan?

Siswa: Hehe, idak Pak.
Guru : Paham idak maksud Bapak tu? Jadi Bapak ulangi sekali lagi. Ini, bacaan singkat ini. Petunjuk cara membersihkan lantai, lumutan atau berlumutan. $\mathrm{Ni}$ ada bacaannya, Bapak ulangi lagi baconyo. Lantai kamar mandi atau sumur yang lumutan mengundang apa? Bahaya kan? Karena licin, kita dapat, tergelincir. Haa, Nah untuk mencegah hal itu, lakukan petunjuk berikut! Satu apa? A, ambil batu merah. Batu Bata Merah. Kurang itu. Ambil Batu merah. Ambil Batu merah. B, gosoklah pada lantai yang lumutan sampai bersih. C, setelah bersih, siramlah dengan air panas. D, ini salah tulis ini. Goklah, gosoklah ini. Gosoklah lagi lantai akan bersih, dan lumutan tidak akan tumbuh kembali. Silahkan! Singkat sekali! Bisa Mad? Ha? Nomor satu Man, Lantai kamar mandi yang berlumutan dapat mengakibatkan titik-titik bagi kita.

Siswa: Diisi pak?

Guru : Di isi. Yang itu kan. Sebutkan urutan. Urutan membersihkan lantai berlumutan dari petunjuk di atas. Ado dak? Petunjuk di atas tadi?

Siswa: Ado.

Nomor data : 2.37

Konteks : Guru menjelaskan materi pembelajaran dengan membaca mengenai materi Petunjuk yang terdapat pada lembar kerja siswa yang sebelumnya telah dibagikan.

Guru: Ha'a, yang bapak kasihkan. Ini adalah petunjuk cara membersihkan apo? Lantai yang berlu?

Siswa: Berlumut.

Guru : Berlumut. Diantaranya, a, ambilah batu, batu merah. Gosoklah pada lantai yang berlumutan sampai bersih. Setelah bersih, siramlah dengan air panas. Kemudian gosoklah, bukan gosoklah lagi lantai 
akan bersih. Dan lumut tidak akan tumbuh kembali.

Siswa: Ngantuk aku ni.

Guru : Belum jugo De?

Siswa: Santai ajo Pak, Ndak Kemano buruburu Pak?

Guru : Kau, Lan? Ambil batu bata merah? Ini yang ini ni, yang nomor tigo ni. Yang nomor tigo sini letaknyo. A, B, C. Nah sebelah sini. Sebelah sini, nomor satu bukan. Nomor satu, Lantai.

Nomor data : 2.63

Konteks : Guru mengecek pekerjaan siswa dengan mendatangi bangku siswa satu persatu, kemudian terdapat siswa yang bertanya mengenai jawaban yang telah dituliskannya.

Guru : Nah.

Siswa: Membersihkan.

Guru : Membersihkan?

Siswa: Lan, lantai yang berlumut. Dari petunjuk di atas.

Guru : Ha. Ini apo yang ado di atas ni? Ini kan bisa, baca ni. Ni kan petunjuk cara membersihkan lantai yang lumutan. Terus baco! Lantai kamar mandi, atau sumur mengundang banyak bahaya. Karena licin, kita dapat tergelincir. Nah. Untuk mencegah hal itu, lakukanlah petunjuk begini, berikut. A, ambil batu merah. B gosok pada lantai yang lumutan sampai bersih. C setelah bersih, siramlah dengan air panas. D, gosoklah lagi, lantai akan bersih. Dan lumut tidak akan tumbuh kembali. Maksudnya, apo namonyo tu.

Siswa: Tergelincir.

Nomor data : 2.77

Konteks : Guru menerangkan kembali isi bacaan petunjuk.

Data nomor (2.37), (2.63), dan (2.77) berisi tuturan yang hampir sama, yang digunakan oleh guru dalam pembelajaran Bahasa Indonesia di kelas VII Tunagrahita SMPLB Dharma Wanita Persatuan Provinsi Bengkulu. Dari ketiga data tersebut terdapat jenis tindak tutur yang sama, yakni tindak menyatakan informasi yang ditandai dengan tuturan " $A$, ambil batu merah. B, gosoklah pada lantai yang lumutan sampai bersih. C, setelah bersih, siramlah dengan air panas. D. Gosoklah lagi lantai akan bersih, dan lumutan tidak akan tumbuh kembali" yang merupakan urutan dari materi teks Petunjuk yang sedang dipelajari oleh siswa. Pengulangan tindak menyatakan informasi tersebut dilakukan oleh guru untuk memberi penekanan dan pemahaman yang lebih kepada siswanya yang memiliki karakteristik kemampuan intelektual di bawah rata-rata yang mengakibatkan siswa tersebut sulit untuk mengingat. Dengan pengulangan tindak yang dilakukan oleh guru tersebut, pemahaman materi yang sulit diingat oleh siswa diupayakan agar teratasi.

\section{Tindak Tutur Direktif}

Ditemukan beberapa variasi tindak tutur direktif dalam penelitian ini, yakni tindak bertanya: 184 tuturan, tindak perintah: 83 tuturan, tindak mengizinkan: 38 tuturan, tindak melarang: 5 tuturan, tindak menasehati: 76 tuturan, dan tindak permintaan: 7 tuturan.

Menurut Yule (2006:93) direktif ialah jenis tindak tutur yang dipakai oleh penutur untuk menyuruh orang lain melakukan sesuatu tuturan. Tuturan direktif menghasilkan suatu efek dari mitra tutur untuk melakukan sesuatu. Tindak direktif yang digunakan oleh guru dalam penelitian ini memiliki perbedaan dengan tindak direktif yang digunakan oleh guru dalam mengajar anak normal pada umumnya. Selain terdapat banyak pengulangan, beberapa tindak direktif bertanya dalam penelitian dituturkan oleh guru secara lengkap dan menggunakan 
padanan kata yang ditegaskan pada tindak direktif, sehingga siswa bisa menjawab pertanyaan tersebut dengan mudah.Berikut merupakan contoh tindak direktif yang digunakan oleh guru.

Guru : Anuar ya? Haa ini. Dia suka main, apa, layang-la?

Siswa: Layang-layang.

Guru : Layang. Suatu ketika layanglayangnya itu putus. Haa. Kemudian karno mengejar layang-layang. Dia melihat keatas. Kakinya tersangkut ke pohon. Dan akhirnya dia terjatuh dan terki? Terkilir. Oleh temannya ini tadi, ditolongnya, dan diantarnya ke? Ke rumahnya. Pulang ke rumahnya. Ibuk samo kakaknya Broto ni ka? Kaget. Kenapa, aponamonyo. Anuar, aponamonyo. Broto. Mungkin menangis ya, sampai ke rumah. Atau merengek-rengek, tidak dijelaskan ya? Kemudian selama dia berobat, dia tidak masuk sekolah selama tiga hari ya. Selama di rumah, kakak dan Ibunya selalu merawat, Broto ini. Kemudian, teman sekolahnya, dari temantemannya dari sekolah.

Menjenguknya datang berkunjung ke? Ke rumahnya. Arman, apanamanya. Broto merasa ter? Terharu.

Haa itu kesimpulannya. Jadi, berhubungan dengan cerita singkat di atas, ini ada beberapa pertanyaan. Sebelum kamu kerjakan. Kamu kasih dulu apa, cara mengerjakannya. Jawablah pertanyaan berikut ini, berdasarkan bacaan yang telah kita baca samasama diatas ni tadi yo! Siapa yang bercerita, pada cerita itu? Siapa yang bercerita ni tadi? Tokoh-tokohnya ni tadi, ado siapa-siapa ni tadi? Yang ado di dalam cerita ni tadi siaposiapo? Namonyo siapo?

Siswa: Broto.
Guru : Broto. Haa, siapo lagi?

Siswa: Anuar.

Nomor data : 3.65

Konteks : Guru menjelakan materi pembelajaran.

Data nomor (3.65) merupakan salah satu contoh tindak bertanya yang digunakan oleh guru dalam pembelajaran Bahasa Indonesia. Pada tuturan tersebut terlihat bahwa pertanyaan yang diberikan beruntut, dengan maksud untuk memperjelas jawaban dari pertanyaan tersebut. Pertanyaan yang beruntut tersebut juga ditandai dengan pengulangan kata yang sama yakni "siapa" yang digunakan dengan penekanan sebagai kunci dari jawaban yang harus dijawab oleh siswa. Hal tersebut dilakukan guru agar siswa yang memiliki kemampuan intelektual yang rendah mampu menjawab pertanyaan tersebut denganbenar.

\section{Tindak Tutur Ekspresif}

Tindak ekspresif yang ditemukan dalam penelitian ini memiliki variasi tindak memuji: 1 tuturan, mengkritik: 31 tuturan, mengeluh: 1 tuturan, menyindir: 7 tuturan, menyalahkan: 15 tuturan, dan tindak berterimakasih: 1 tuturan. Jika dibandingkan dengan temuan sebelumnya, yakni tindak asertif dan direktif, tindak tutur ekspresif yang digunakan jumlahnya lebih sedikit. Hal tersebut dapat disesuaikan dengan upaya guru yang lebih banyak menjelaskan dan memberi pemahaman mengenai materi pembelajaran dibandingkan menunjukkan pernyataan-pernyataan psikologisnya yang merupakan reaksi dari karakteristik siswanya.

Menurut Yule (2006: 93) ekspresif ialah jenis tindak tutur yang menyatakan sesuatu yang dirasakan oleh penutur. Tindak tutur itu mencerminkan pernyataan-pernyataan psikologis dan dapat berupa pernyataan kegembiraan, kesulitan, kesukaan, kebencian, 
kesenangan, atau kesengsaraan. Tindak tutur ekspresif yang digunakan oleh guru dalam penelitian ini sangat berkaitan dengan kondisi siswa yang memiliki hambatan kemampuan intelektual dengan demikian tindak ekspresif yang digunakan oleh guru yang mengajar anak Tunagrahita berbeda dengan tindak yang digunakan guru di sekolah umum. Tindak ekspresif yang digunakan oleh guru mengandung bahasa yang halus dan mudah dipahami. Berikut merupakan salah satu contoh tindak menyalahkan yang digunakan oleh guru.

Guru : Jawabannyo kan ado di sini. Ado galo di sini. Mangkonyo kato Bapak, Tinggal me... me... apo namonyo, memindahkan.

Siswa: Nah, Bapak.

Guru : Broto, betul

Siswa: Sala pak, salah bae pak, nomor tigo Pak.

Guru : Di mana dia tinggal? Di sebuah desa. Apo pekerjaan orang tuanyo, polisi dan ibunya. Dak usah! Pekerjaan, Boleh sebutkan pekerjaan, pekerjaan bapaknyo. Bapaknyo sebagai polisi, dan ibunyo sebagai ibu?

Siswa: Rumah tangga,

Guru : Ibu rumah tangga, boleh! Apa pekerjaan sebagian besar penduduk? Tembakau. Haa, ini kurang pas ini, apo tadi? Petani dan?

Siswa: Salah Pak?

Guru : Peternak. Kurang pas ini. Salah.Bukan menanam tembakau. Bagaimana kondisi air di sana. Bagaimana penduduk mendapatkan air bersih, dari sumur. Haa iyo. Kenapa Broto dibawa ke puskesmas? Karena terjatuh dan terkilir. Betul. Lalan mano lan? Kasih nilai sini Lan.

Siswa: Ini, kacau.

Guru : Slamat sudah ditulis tadi Mad? Sudah? Sini!
Nomor data : 3.262-3.263

Konteks : Guru mengoreksi tugas yang dikerjakan oleh siswa.

Data tuturan nomor (3.262-3.263) berisi tuturan yang menyalahkan jawaban dari mitra tutur sesuai dengan konteks penutur sedang mengoreksi tugas dari mitra tutur termasuk ke dalam tindak tutur ilokusi ekspresif menyalahkan. Dalam tindak menyalahkan yang ditandai dengan petranda lingual "Kurang pas ini. Salah. Bukan menanam tembakau." Dapat diketahui bahwa guru menggunakan bahasa yang halus dalam memberi pemahaman kepada siswa.

\section{Tindak Tutur Deklaratif}

Menurut Yule (2006:92) Direktif adalah jenis tindak tutur yang mengubah dunia melalui tuturan. Penutur harus memiliki peran institusional khusus, dalam konteks khusus untuk menanpilkan deklarasi secara tepat. Tindak deklaratif dalam penelitian ini jika dikaitkan dengan konteks penutur yang merupakan seorang guru yang mengajar siswa yang memiliki hambatan intelektual memiliki keunikan tersendiri, dikarenakan siswa yang sulit untuk menerima informasi, maka tindak deklaratif yang digunakan oleh guru dalam penelitian ini hanya berupa tindak memutuskan sebanyak 5 tuturan. Tindak deklaratif memutuskan yang digunakan oleh guru disertai dengan tuturan yang mudah dipahami dan pengulangan beberapa fungsi gramatikal, hal tersebut dilakukan agar siswa mengerti maksud yang dideklarasikan oleh guru. Berikut merupakan contoh tindak memutuskan yang digunakan oleh guru.

Guru : Kau dak nulis, kau?

Siswa: Idak Pak.

Guru : Velba tulis! Waktunyo, habis waktunya.

Siswa: Habis udem.

Guru : Tulis! Tinggal nyalin me... memindahkan. 
Nomor data : 2.148

Konteks : Guru mengecek tugas siswa satu persatu dan memgingatkan siswa untuk segera menyelesaikan tugasnya.

Data (2.148) tersebut termasuk ke dalam tindak memutuskan, guru mendeklarasikan bahwa pertanyaan dalam lembar kerja yang telah dibagikan kepada siswa akan dikoreksi bersama oleh guru dan siswa. Berdasarkan data tersebut tampak bahwa tuturan deklaratif yang digunakan oleh guru menggunakan pengulangan kata. Pengulangan tersebut dilakukan dengan menggunakan bahasa bengkulu "waktunyo" dan bahasa Indonesia "waktunya", hal tersebut dilakukan oleh guru agar siswa memahami maksud pendeklarasian yang disampaikan oleh guru.

\section{PENUTUP}

\section{Simpulan}

Berdasarkan hasil penelitian yang telah dilakukan dapat disimpulkan sebagai berikut.

1. Wujud tindak asertif yang digunakan oleh guru yang mengajar di kelas VII Tunagrahita meliputi tindak menyatakan yang memiliki variasi tindak menyatakan informasi: 45 tuturan, tindak menyatakan pemberitahuan: 20 tuturan, menyatakan contoh: 5 tuturan, dan menyatakan pembenaran: 29 tuturan. Selanjutnya ditemukan pula tindak mengakui: 3 tuturan, tindak menunjuk: 37 tuturan, tindak mempertahankan: 12 tuturan, tindak menyebutkan: 3 tuturan, tindak membantah: 7 tuturan, dan tindak mengucapkan salam: 3 tuturan.

2. Wujud tindak direktif yang digunakan oleh guru dalam penelitian ini terdapat beberapa variasi, yakni tindak bertanya: 184 tuturan, tindak perintah: 83 tuturan, tindak mengizinkan: 38 tuturan, tindak melarang: 5 tuturan, tindak menasehati: 6 tuturan, dan tindak permintaan: 7 tuturan.

3. Wujud tindak ekspresif yang digunakan oleh guru dalam penelitian ini memiliki variasi tindak memuji: 1 tuturan, mengkritik: 31 tuturan, mengeluh: 1 tuturan, menyindir: 7 tuturan, menyalahkan: 15 tuturan, dan tindak berterimakasih: 1 tuturan.

4. Wujud tuturan deklarasi yang ditemukan dalam penelitian ini terdapat 5 tuturan yang termasuk tindak memutuskan.

\section{Saran}

Dari penelitian penelitian yang telah dilakukan mengenai " Tindak Tutur Guru dalam Pembelajaran Bahasa Indonesia di kelas VII Tunagrahita SMPLB Dharma Wanita Persatuan Provinsi Bengkulu Tahun Ajaran 2016/2017" diharapkan dapat diteliti lebih lanjut mrngenai tindak ilokusi yang digunakan oleh Guru dalam mengajar Bahasa Indonesia terhadap anak berkebutuhan khusus terutama anak Tunagrahita sehingga diketahui jenis tindak tutur yang paling efektif digunakan dalam oleh Guru mengajar anak tersebut.

\section{DAFTAR PUSTAKA}

Chaer, A.d. 2010. Sosiolinguistik Perkenalan Awal. Jakarta: PT Rineka Cipta.

Delphie, B. 2009. Psikologi Perkembangan (Anak Berkebutuhan Khusus). Klanten: PT Intan Sejatih.

Ilahi, M. T. 2013. Pendidikan Inklusif. Yogyakarta: Ar Ruz Media. 
Leech, G. 1993. Prinsip-Prinsip Pragmatik. Jakarta: Penerbit Universitas Bengkulu.

Mahsun. 2007. Metode Pebelitian Bahasa (Tahapan strategi, metode, dan tekniknya). Jakarta: PT Grafinco Persada.

Sugiyono. 2008. Metode Penelitian Pendidikan Pendekatan Kuantitatif, Kualitatif, dan R\&D. Bandung: Alfabeta.
Susetyo. 2015. Penelitian Kuantitatif dan Penelitian Tindakan Kelas. Bengkulu: Fakultas Keguruan dan Ilmu Pendidikan.

Tirtarahardja. 2010. Pengantar Pendidikan. Jakarta: PT Rineka Cipta.

Yule, G. 2006. Pragmatik. Yogyakarta: Pustaka Pelajar. 